\title{
Targeting the Gut Microbiome to Ameliorate Cardiovascular Diseases
}

\author{
Soonjae Hwang, Chan Oh Park and Ki-Jong Rhee ${ }^{\dagger}$ \\ Department of Biomedical Laboratory Science, College of Health Sciences, \\ Yonsei University at Wonju, Wonju, Gangwon-do 220-710, Korea
}

The bacterial cells located within the gastrointestinal tract (GIT) outnumber the host's cells by a factor of ten. These human digestive-tract microbes are referred to as the gut microbiota. During the last ten years, our understanding of gut microbiota composition and its relation with intra- and extra-intestinal diseases including risk factors of cardiovascular diseases (CVD) such as atherosclerosis and metabolic syndrome, have greatly increased. A question which frequently arises in the research community is whether one can modulate the gut microbial environment to 'control' risk factors in CVD. In this review, we summarized promising intervention methods, based on our current knowledge of intestinal microbiota in modulating CVD. Furthermore, we explore how gut microbiota can be therapeutically exploited by targeting their metabolic program to control pathologic factors of CVD.

Key Words: Gut microbiome, Cardiovascular diseases, Atherosclerosis, Metabolic syndrome

\section{서 론}

지난 20년 동안, 장내 세균총 군집과 대사 증후군이나 죽상동맥경화증과 같은 심혈관 질환(cardiovascular disease; $\mathrm{CVD}$ )과의 연관성에 대해 많은 연구가 진행되었으며 장내 세균총 분야에서는 사람의 장내 세균총 군집 변화를 인위 적으로 유도하여 심혈관 질환 위험 인자들을 개선시키기 위한 노력들이 이루어 지고 있는 실정이다(Caesar et al., 2010; Nicholson et al., 2012; Tang and Hazen, 2014). 그에 따 라, 본 논문에서는 이때까지 기초실험 및 임상적 연구 논 문에 근거하여 심혈관 질환 발병을 증가시키는 병인 인자 들을 조절하기 위한 이때까지 행해진 여러 개선 전략에 대해 요약하였으며, 추후에 장내 세균총 및 장내 세균총 에 의한 대사체를 표적으로 하는 치료 연구에도 이용할 수 있을 것으로 사료된다.

비만, 인슐린 저항성, 암과 같은 선진국형 질환은 최근
현대인의 주요 질환으로 인식되고 있으며, 최근 연구 결 과들에 의하면 장내 상재하는 균총이 직접적으로 장관 내 항상성 유지에 관여할 뿐만 아니라 간접적으로 장관 외 조직 및 기관에서 발생하는 질환의 발병 및 치료에 주요 한 영향을 미친다고 알려져 있다(Round and Mazmanian, 2009; Kinross et al., 2011).

52개의 bacterial phyla 중에서도 5 7개의 phyla가 포유 동물의 장관계에 존재하고 있으며, 그 중에서도 Firmicutes 와 Bacteroides가 주요한 phyla로 알려져 있다(Shin et al., 2015). 사람이 출생과 동시에 많은 미생물이 장에 거주하 기 시작하며, 장관 내 급격한 증식이 수반된다. 결과적으 로 장 내강에 장내 세균의 수는 사람의 세포 수보다 많 은 개체 수를 구성하게 된다. 이렇게 생성된 장내 세균 총은 시간이 지나, 균총을 지닌 개체의 나이도 증가함 에 따라 군집의 분포가 달라지게 된다고 알려져 있으며 Proteobacteria phyla는 유년기( 16\%)에서 성인( $4.6 \%)$ 때 까지 장에서 우세하다(Shin et al., 2015). 장내 세균총은 내

*Received: September 5, 2017 / Accepted: September 17, 2017

${ }^{\dagger}$ Corresponding author: Ki-Jong Rhee. Department of Biomedical Laboratory Science, College of Health Sciences, Yonsei University, Wonju 26493, Korea. Tel: +82-33-760-2445, Fax: +82-33-760-2195, e-mail: kjrhee@yonsei.ac.kr

(C) The Korean Society for Biomedical Laboratory Sciences. All rights reserved.

(c) This is an Open Access article distributed under the terms of the Creative Commons Attribution Non-Commercial License (http://creativecommons.org/licenses/by-nc/3.0/) which permits unrestricted non-commercial use, distribution, and reproduction in any medium, provided the original work is properly cited. 
분비 기관처럼 사람의 생리학에 영향을 주는 대사체 활동 을 하는데 예시로는 incretin과 peptide $\mathrm{YY}$ 와 같은 장관계 호르몬의 방출을 촉진하기도 한다(Cani et al., 2009a). 장내 세균총의 분포는 매일 섭취하는 음식의 성분에 따라서 빠 르게 바뀌고 변화한다(Wu et al., 2011; David et al., 2014). 먹는 음식물의 성분에 따라 변화하는 장내 세균총의 군집 은 때때로 숙주가 가진 기저 질환에 역효과를 내기도 한 다. 예를 들자면 섬유소가 적으나, 칼로리가 높은 음식을 자주 섭취하는 식습관은 염증성 장질환(inflammatory bowel diseases; IBD)과 대사성질환(metabolic disorders)를 가지고 있는 환자들에게서 많이 관찰되었다(Carvalho et al., 2012; Shin et al., 2015). 특히, 증가된 Firmicutes/Bacteroidetes 비 율은 심혈관 질환의 잠재적 위험 인자들과 밀접한 연관이 있다고 연구된 바 있다(Turnbaugh et al., 2006; De Filippo et al., 2010; Shin et al., 2015).

장내 세균총이 장내 환경 및 건강에 미치는 역할 및 효 능에 대한 연구는 광범위하게 이루어졌지만, 장내 세균총 이 장관계 이외의 질환 및 타 장기의 면역 시스템에 미치 는 영향에 대한 탐색 및 이와 관련하여 밝혀진 연구 결과 는 제한되어 있는 실정이며, 특히 심혈관 질환과 장내 세 균총과의 관계에 대해 수행된 기초 및 임상 연구가 미흡 한 실정이다. 염증성 장질환 환자들은 coronary heart disease 에 대해 정상인에 비해 더 높은 위험도를 가지고 있다고 조사된 바 있으나, 염증성 장질환 자체가 일반적인 심혈 관 질환에 대해 주요한 위험 인자들 중에 하나로 간주되 고 있지 않다(Raftery and O'Sullivan, 2011; Andersen and Jess, 2014; Wu et al., 2017). 장과 심장을 서로 연결하여 심혈관 질환을 이해하려는 이론적 배경으로는 장내 세균이 만들 어 낸 대사산물 및 장내 세균을 이루고 있는 구성체가 틈 이 많은 장내 장벽을 흡수 또는 통과한다고 알려져 있다 (Krajmalnik-Brown et al., 2012). 체내 심장 순환 시스템을 통해 장내 세균총에 의해 생성, 변환 및 유래된 물질의 유 입이 전신적으로 이루어 지게 되면 metabolic endotoxemia 를 야기하게 되어, 결론적으로 장을 제외한 타 조직 내 약 한 염증을 야기할 거라는 실험적 근거들이 존재한다(Cani et al., 2008; Cani et al., 2009b). 최근 발표된 한 연구에 의 하면, 항암제를 이용한 화학 치료를 받는 암환자들의 혈 액 내에 그람 음성 세균의 성분인 내독소(endotoxin)의 농 도가 높다고 임상적으로 연구된 바 있으며, 실험 동물을 이용한 연구 문헌에서도 화학 치료에서 가장 많이 사용 되는 약물인 doxorubicin을 투입하게 되면, 장내 장벽을 이 루는 장 상피세포의 세포사멸로 인해, 장내 장벽의 투과
성이 증가되며(Mackensen et al., 1991; Engervall et al., 1995; Lundin and Checkoway, 2009), 장내 내독소의 전신적 혈류 내 유입으로 인해 간, 신장, 심장에 대해 약한 염증을 유 발하여 조직 내 손상을 야기하는 것으로 보고된 바 있다 (Wang et al., 2016). 하지만 장내 세균총으로 인해 유도된 대사물질이 죽상동맥경화 또는 다른 심혈관 질환을 어떻 게 영향을 미치는 지에 대해서는 기전 연구가 밝혀진 바 없으며 현재 이와 관련한 많은 연구가 수행되고 있는 실 정이다. 본 논문에서는 장내 세균이 심혈관 질환에 어떠 한 역할을 할 수 있는지에 대해 추론할 수 있는 연구 결 과들과 현재 장내 세균을 표적으로 진행되고 있는 전략들 에 대해 살펴보고자 한다.

\section{장내 세균총, 대사 증후군, 심혈관 질환의 연관성}

비만, 인슐린 저항성, 고혈당증, 고지질증, 고혈압증을 다같이 아울러 하나의 용어로 대사 증후군이라 지칭하며 방금 언급된 6개 요인은 대표적인 심혈관 질환의 위험 인 자로 알려져 있다(Shin et al., 2017). Kumar 연구 그룹에서는 TLR5가 유전적으로 결핍된 마우스에서 장내 세균총 불균 형이 과식증(hyperplagia)를 야기하였고, 대사 증후군이 발 달되어 나타날 때에 과식증 현상이 증가함을 밝혀 보고한 바 있다(Carvalho et al., 2012; Singh et al., 2015). 장내 내강에 존재하던 혈액 내 장내 세균이 장내 점막 조직으로 LPS 유입으로 인한 metabolic endotoxemia가 대사 증후군으로 진행된다는 연구 가설을 앞서 언급한 Kumar 연구 그룹에 서 발표한 실험 결과가 일정 부분을 지지해 주기도 하지 만, 항상 미생물의 metabolites가 몸에 해로운 방향으로 작 용하는 것은 아니다. 예를 들어, 미생물로 유래된 shortchain fatty acids (SCFA: acetate, butyrate, propionate)는 숙주 에게 탄소 및 에너지원으로써 유익이 되기도 한다. 실제 로 SCFA가 비만, 식욕, 대장 내 염증에 대해 이로운 방향 으로 미치는 영향에 관한 연구 결과들은 많이 발표되어 있는 실정이다(Furusawa et al., 2013; Frost et al., 2014; den Besten et al., 2015). 그럼에도 불구하고 대사 증후군이 있 는 사람의 분변에는 SCFA가 유의하게 증가한다는 임상 연구 결과가 보고된 바 있다(Teixeira et al., 2013; Fernandes et al., 2014). 이와 유사하게, Kumar 연구 그룹에서는 마 우스의 장에서 균형이 깨진 장내 세균총으로부터 생산된 $\mathrm{SCFA}$ 가 조절되지 못하고, 만성적으로 장 내강에서 생산 되어 TLR5가 결핍된 마우스에서 대사 증후군을 촉진시키 는 역할을 한다는 것이 밝혀진 바 있다(Singh et al., 2015). 
장내 세균총으로부터 생성된 SCFA에 의해서 대사 증후 군으로 발전된다는 마우스 연구 결과와 고지방식을 시켜 준 rat의 장내에서 propionate/acetate를 생성하는 Phascolarctobacterium, Proteus mirabilis, Veillonellaceae 가 증가한다 는 연구 결과와 연결지어 비추어보면, 오랜 고지방식으로 인한 SCFA를 만들어내는 특정 장내 세균 군집의 증가로 인해 오랜 기간 동안 $\mathrm{SCFA}$ 가 만들어지게 되고 그 결과 로 실험 동물뿐만 아니라 사람에게서도 대사 증후군이 매 개될 수 있다는 연구 결과의 임상적 중요성을 나타낸다 (Lecomte et al., 2015).

죽상동맥경화증은 심혈관 질환 중에서도 위험성이 높 다고 알려져 있다(Kwon and Na, 2016; Lim and Kim, 2017). Koren et al.에 의해 수행된 연구 결과에 따르면 사람의 죽상동맥경화증에 해당되는 병변에서 세균의 DNA가 일 부 관찰되었으며, 병변 내 세균의 DNA의 양은 plaque에 존재하는 백혈구의 수와 양의 상관관계로 비례한다고 보 고된 바 있다(Koren et al., 2011). 더욱이, 증가된 혈장 콜레 스테롤 수치는 구강 및 장내 여러 세균의 분류군의 변화 와 양의 상관관계가 있다고 보고된 바 있다. 치석을 생성 하는 Veillonella와 죽상동맥경화의 plague 내에 존재하는 Streptococcus bacterial DNA의 확인은 죽상동맥경화증의 원인의 일부가 세균이 매개할 수도 있다는 개연성을 나타 내기도 한다(Koren et al., 2011).

최근 죽상동맥경화증과 관련한 연구 결과에서는 proatherogenic molecule trimethylamine N-oxide (TMAO)를 생성 하는 장내 세균총에 대해 보고된 바 있다(Tang et al., 2013). 구체적으로, 음식물 섭취로 얻는 choline과 L-carnitine은 장 내 세균총에 의해 대사되어 trimethylamine (TMA)이 생성 되는데 $\mathrm{TMA}$ 는 추가적으로 간에 존재하는 flavin monooxygenase 3 (FMO3)에 의해 TMAO로 변환된다(Koeth et al., 2013). 마우스가 먹는 사료에 choline 또는 TMAO를 첨가하여 주었을 때, 주변 조직에서 간으로 혈액을 통해 콜레스테롤이 이동하는 역방향의 콜레스테롤 수송을 저 해하며, 마우스에서 죽상동맥경화증이 선행되기 전에 생 성되는 foam cell 생성을 촉진한다. 마우스 사료에 함유된 choline 또는 TMAO로 인해 유도되는 대사 증후군이 장 내 세균총을 매개로 유발된다는 연구 가설을 증명하기 위 해 형성하는 대장 내 세균총 이식을 죽상동맥경화증이 발 생하는 apolipoprotein E-deficient 마우스에 이식해 주었을 때, 발생되는 plaque의 병변이 통계적으로 유의하게 증가 하였음이 관찰되었다(Koeth et al., 2013). 사람을 대상으로 한 임상 연구에서도, 혈장 내 존재하는 $\mathrm{TMAO}$ 농도가 증
가할수록 주요 심혈관 질환의 발병 및 병리적 지표와 양 의 상관관계가 있다고 보고된 바 있다(Tang et al., 2013).

현재까지 장내 세균총과 심혈관 질환과의 관계에 대한 연구들은 기본적인 수준에 머물러 있으며, 장내 세균총이 심혈관 질환에 대한 미치는 기초적 기전 연구가 활발히 진행되고 있는 실정이다. 장내 세균총이 심혈관 질환의 발 병 및 병리 기전에 미치는 영향에 대해 분자 수준에서 이 해하게 되면, 이를 바탕으로 장내 미생물이 만들어 내는 대사과정에 관여할 수 있는 비생물학 및 생물학적 제제들 을 이용한 치료 기술이 크게 발전할 가능성이 높으며, 이 에 따라 기존 약물의 효능을 개선 및 부작용 감소로 이어 질 수 있을 것으로 전망되고 있는 실정이다. 장내 세균총 을 이용하여 심혈관 질환의 발병을 감소시키기 위한 전략 개발 및 연구에 대해 많은 관심이 집중되고 있다.

\section{심혈관 질환 치료를 위한 치료 표적: 장내 세균총의 물질대사}

장내 세균총의 물질대사는 숙주의 물질대사를 조절할 수 있는 중요 인자로 알려져 있다. 이러한 개념에 근거하 여, 연구자들은 장 내에 특정 물질의 대사 활동을 약학적 관점에서 간섭 또는 조절할 수 있는지 시도하였다. 예를 들면, carnitine의 aza-analogue 제제가 식이를 통해 섭취 되는 quarternary amine이 미생물에 의해 분해되는 과정 에 간섭함으로써, 죽상동맥경화증을 촉진시키는 대사물 질인 $\mathrm{TMAO}$ 의 생산을 억제할 수 있는 가능성을 보여준 연구 결과가 있다(Kuka et al., 2014). 더불어 Methanomassiliicoccus luminyensis $\mathrm{B} 10$ 라는 고세균을 죽상동맥경화 증이 발병하는 마우스 모델에 적용하여 $\mathrm{TMAO}$ 의 전구체 인 TMA라는 물질을 반응성이 없는 상태로 바꿈으로써 $\mathrm{TMAO}$ 생산을 감소시키는 연구 결과가 보고된 바 있다 (Brugere et al., 2014). 이를 통해 고세균을 이용하여 심혈관 질환을 악화시키는 미생물총의 대사과정을 조절 및 변화 시킬 수 있는 치료 가능성이 알려진 바 있다.

\section{대변 이식: 개인의 장내 세균총의 재구축}

대변 세균총 이식(fecal microbiota transplantation)은 위장 관 질환이 있는 환자들에게 건강한 사람의 대변 내용물을 직접적으로 환자의 장으로 투입함으로써 인체에 유해한 장내 세균의 수를 감소시키고, 다시금 건강하게 회복하게 하기 위해 고안된 방법이다(Gough et al., 2011). 대변 세균 
총 이식은 1960년 후반으로 부터 치료로 사용될 수 있는 개념으로 인식되었으나, 대변 세균총 이식은 최근 6 9년 동안 장내 세균총에 개선시킴으로써 직접적인 장내 질환 치료 및 타 질환 치료 가능성을 염두에 두고 많은 관심과 이목을 받고 있고 현재도 많은 응용 가능성이 탐색되고 있는 실정이다. 구체적 사례로는, 사람에게서 발생한 재발 성 Clostridium difficile 감염증에 대해 대변 세균총 이식을 적용하여 치료 효과가 입증된 바 있다(Bakken et al., 2011; Rohlke and Stollman, 2012). 현재 많은 연구자들은 대변 세 균총 이식을 장내 질환뿐만 아니라, 장내 세균총에 의해 매개되는 장 이외의 질환에 대한 차세대 치료법으로 인식 하고 있다. 장 이외의 질환에 대해 대변 세균총 이식을 적 용한 임상 연구로는, 마른 사람의 대변을 비만인 사람에 게 이식하여 주었을 때, 인슐린에 대한 체내 반응성을 증 가시키고 혈중 중성지방 수치를 개선에 효과가 있음을 확 인된 바 있다(Vrieze et al., 2012). 하지만, 대변 세균총 이 식은 건강한 사람이라 하더라도 잠복기의 형태로 가지고 있는 균에서 유래한 내독소 및 감염성 미생물을 완전히 배제할 수 없다는 제한 점이 존재하며 감염성 미생물이 포함된 대변 이식을 통해 기존 장 및 타 장기의 질환이 더 심해질 가능성도 존재하기 때문에(Schwartz et al., 2013), 건강한 사람의 대변에 대한 처리방식 및 안전한 대변이라 는 정의에 대해 논의가 진행되고 있는 실정이다. 더불어, 건강한 사람이라도 사람마다 가진 장내 세균총의 분포는 규격화된 제품처럼 똑같지 않기 때문에(Lozupone et al., 2012), 안전하다고 알려진 특정 균주들의 조합(Altered Schaedler Flora)을 찾아 이식하고자 하는 연구도 진행되 고 있는 실정이다(McCarthy et al., 2011; Shen et al., 2015; Wymore Brand et al., 2015).

\section{유전적으로 조작된 유산균}

사람의 장은 광범위한 미생물들의 조합을 수용할 수 있 는데, 장 내에 작은 비율로 존재하는 특정 균주들은 유산 균들과 같은 유익한 효능을 지닌다고 보고된 바 있으며 이런 특정 균주들을 이용하여 심혈관 질환을 악화시킨다 고 알려진 인자들을 조절하는 미생물 제제로 사용될 수 있다. 예를 들자면, bile-salt를 가수분해 시킬 수 있는 효소 를 가진 Lactobacillus reuteri NCIMB 30242 균주가 담긴 캡 슐을 고콜레스테롤 혈증 증상을 보이는 성인에게 오랜 기 간 동안 먹여주었을 때, 대조군과 달리 시간이 지남에 따 라 혈중 내 콜레스테롤 수치가 개선이 통계적으로 유의하
게 되었으며, Lactobacillus reuteri NCIMB 30242 균주를 통 해 장 내강에 존재하는 bile-acid의 deconjugation를 유도함 으로써 콜레스테롤을 낮추는 주된 치료법과 더불어 사용 될 수 있는 보조적 치료로 접근될 수 있음이 확인되었다 (Jones et al., 2012). 다른 연구에서는, 몸에 유익한 효과를 내는 균주를 유전적으로 조작하여 기존에 지닌 이로운 효 능을 향상시켜 특정 질환을 치료하려는 접근도 증가하고 있는 실정이다. 예를 들자면, N-acylphosphatidylethanolamines 를 발현하는 Escherichia coli Nissle 1917 균주는 고지방식 으로 유도되는 비만을 경감 및 완화시킬 수 있는 유전적 으로 조작된 균주 중 하나로 알려져 있다(Chen et al., 2014). 이와 비슷한 치료 표적으로는, intestinal alkaline phosphatase 가 있으며 위 효소는 그람 음성 세균의 LPS에 존재하는 lipid A 부분에 존재하는 인을 탈인산화 시킴으로써, LPS 의 독성 효과를 결과적으로 불활성화시키는 기능을 한다 고 잘 알려져 있다(Lalles, 2010). 따라서, 위와 같은 치료적 인 목적으로 개선 또는 새로운 기능이 추가된 유전자 조 작 유익 균주들을 이용하여 장 내강의 LPS 및 대사 증후 군과 관련된 지표들을 개선시키는 전략이 추후에 임상 치 료 현장에서 접목될 수도 있다.

\section{식이적 조절: 건강 개선 및 질환 치료를 위한 음식}

많은 환경적 요인 중에서도, 식이는 장내 세균총의 구 성을 바꾸는 있는 주요 인자 중 하나로 알려져 있다. 섬유 소가 풍부한 식단은 몸에 이로운 장내 상재균의 성장을 촉진시키고 결과적으로 기회 감염균의 성장을 제한 또는 저해할 수 있다(Foye et al., 2012). 식이와 장내 세균총의 관계를 이해하고 임상적으로 의약품을 대체할 만한 바이 오 의료기술개발을 위해, 많은 연구자들은 치료적 효과가 있는 기능성 식품들의 조합 및 구성에 대해 연구하기 시 작하였다. 최근에, 한 연구에서는 통밀, 전통 중의학 식품, 대장 내 유익 미생물들의 증식 및 기능을 향상시킬 수 있 는 식품을 이용한 식이적 조절은 기회 감염균인 Enterobacteriaceae을 감소시키고, 장내 장벽을 보호해주는 Bifidobacteriaceae의 성장을 촉진시키며, 그와 동시에 인슐린 반 응성 및 지방과 관련된 대사적 지표들의 개선도 수반됨 을 보고한 바 있다(Xiao et al., 2014).

구체적으로 예를 들자면, inulin-type 프리바이오틱스와 같은 식이적 화합물들은 장에 Bifidobacteria와 같은 유익 한 균의 성장을 촉진시키는 유익한 효능을 가지고 있다 
고 보고된 바 있다(Kelly, 2008; Kleerebezem and Vaughan, 2009). 추가적으로, 프리바이오틱스의 종류인 polydextrose 와 프로바이오틱스의 종류인 Bifidobacteria B420 균주를 동시에 인슐린 저항성이 나타나는 마우스에 같이 처리 시 혈당 및 인슐린 저항성이 개선됨이 확인된 바 있다 (Stenman et al., 2015).

유익 군주들에게 기능 향상 및 증식을 도와주는, 수용 성의 섬유소는 미생물에 의한 발효를 통해 SCFA라는 물 질들을 생산을 유도하며 만들어진 $\mathrm{SCFA}$ 는 심혈관 질환 의 위험 인자들을 개선 및 완화시킬 수 있는 체내 유익한 효능을 발휘한다고 보고된 바 있다(Furusawa et al., 2013; Frost et al., 2014; den Besten et al., 2015). SCFA는 심장 장기 에 대해 유익한 효과를 내도록 치료적으로 이용될 수도 있지만, 아직 이에 대한 장기간의 연구 기간을 통해 장기 적 SCFA가 나타낼 수 있는 예상치 못한 체내 효과에 대 해서도 평가할 필요가 있다. 왜냐하면, 앞서 언급한 바와 같이 대사 증후군을 가진 임상 환자들의 대변 내에서 $\mathrm{SCFA}$ 의 수치가 만성적으로 증가해 있었으며, 특히 2형 당뇨병을 가진 환자들을 대상으로 연구한 임상 연구 결과 에서는 SCFA가 대변 내에 유의하게 증가해 있었기 때문 에 치료적 목적을 가지고 인위적으로 섭취하는 기능성 식 품의 안정성 또한 연구되어야 할 필요가 있다(Wolever et al., 2002).

종합적으로 앞서 관찰된 연구 결과들을 살펴보면, 특정 식품 및 효능을 가진 균주를 이용하거나 장내 세균총을 건강한 사람의 세균총으로 이식하려는 치료적 접근은 안 전성 및 임상에 적용하였을 때의 기대 효과에 대해 의견 이 분분할 수 있으나, 심혈관 질환에 대한 치료로 쓰이는 기존 약제에 대해 보완 및 대체할 수 있는 흥미로운 방법 중에 하나가 될 수 있을 것으로 사료된다.

\section{심혈관 질환을 악화시키는 위험 요인들을 감소시키는 예방적 접근: 건강한 장내 세균총 군집 유지}

장내 세균총 군집을 치료적인 관점에서 변화를 유도함 으로써, 건강을 증진시킬 수도 있으며 항생제를 통해 사 람의 장내 세균총 군집에 큰 변화를 유도할 수도 있지만, 항생제를 이용한 방식은 이점보다 몸에 해로운 점이 더 많을 수 있다. 예를 들자면, 생후 6달 이내에 사람에서의 항생제 처방 및 사용은 소아 비만과 밀접한 상관관계가 있다고 보고된 바 있다. 이를 지지하는 유사한 결과 또한
마우스를 이용한 기초 연구에서 관찰된 바 있다(Cho et al., 2012; Trasande et al., 2013). 꽤 놀랍게도, 죽상동맥경화증이 유발되는 ApoE-KO 마우스에 저콜레스테롤 식이를 먹임 과 동시에, 미생물이 없는 germ-free 시설에서 유지될 경 우에, 일반 미생물 사육시설에서 사육된 ApoE-KO 마우 스에 비해 훨씬 더 심각한 죽상동맥경화증으로 발전한 연 구 결과가 보고된 바 있다(Stepankova et al., 2010). 위 연구 결과를 통해 장내 세균총과 장내 세균총으로 대사된 산물 들에 의해 심혈관 질환에 대하 보호 및 예방해주는 효과 들 또한 존재하는 것이 실험적으로 확인되었다.

아울러 이러한 연구 결과들이 의미하는 바는 장내 세균 총을 매개로 한 질환을 가진 환자를 치료하기 위해서는 단순히 질환을 유도 및 악화시키는 장내 세균총을 제거하 면서 동시에 기존에 존재하는 유익한 미생물도 보존할 수 있는 방향으로 장내 세균총 치료 분야가 나아가 함을 의 미한다.

\section{박테리오파지를 이용한 장내 세균총 개선 및 치료}

박테리오파지(bacteriophage)는 세균에 특이적으로 침투 하며, 용균시키는 바이러스이다. 위와 같은 특성을 이용하 여 박테리오파지를 병원성을 가지는 특이 대한 감염증 치 료에 쓰이기도 하였으며, 박테리오파지 치료는 80년 전 박테리오파지를 최초로 발견한 Felix d'Herelle에 의해 소 개된 적이 있다(Ho, 2001; Summers, 2001). 하지만, 1940년 이후에 여러 항생제들의 개발이 이루어지면서 박테리오파 지를 이용한 치료법에 대한 관심도 감소하며, 대중적인 치료법 중에 하나로 발전되지 못하였다. 광범위 미생물에 대해 효능을 가진 항생제보다 뒤쳐졌던 이유로는 박테리 오파지는 특정한 세균에만 감염하는 특징 때문에 초기 개 발되었던 항생제에 비해 과학자 및 임상 의사에게 매력적 으로 다가오지 못했다. 그 이유로는, 개발된 항생제에 대 한 저항성을 가지는 항생제-내성 균주들이 그 당시에는 크게 문제되지 않았기 때문이다. 하지만, 점진적으로 개발 된 항생제들에 저항성을 가진 병원성 균주들이 발견되고 살아남게 되면서 새로운 항생제 개발을 통해 위 부분을 상쇄해보려 하였지만, 한 종류의 항생제를 개발하기 위해 요구되는 시간과 개발 비용이 크기 때문에, 개발 기간과 개발 비용이 적은 박테리오파지에 대한 관심이 최근 대두 되고 있는 실정이다(Loc-Carrillo and Abedon, 2011). 항생제 의 지속성은 체내에서 사라지기 때문에, 박테리오파지는 
특성 세균이 존재하는 한 지속성이 있으며, 내성 세균에 대한 극복 능력 또한 박테리오파지는 자연적 유전자 돌연 변이 기작을 통해 같이 진화함으로써 극복할 수 있다는 장점이 있다(Loc-Carrillo and Abedon, 2011). 초기 치료용 박테리오파지는 기술적 문제로는 박테리오파지를 많이 증 식시키기 위해 숙주 세균과 같이 배양하여 박테리오파지 의 수를 늘리는 과정에서 숙주 세균이 가진 내독소 함유 및 미제거로 인한 안전성 문제가 대두된 적이 있다. 하지 만 최근엔 분리 및 정제 기술의 진보로 인해 장비가 발전 함에 따라 이러한 문제는 사라지게 되었으며, 차세대 항 생제 내성 균주 감염증에 대한 치료법 및 장내 세균총 개 선 제제 후보로 주목 받고 있다.

\section{결 론}

최근에는 맞춤화된 의료 서비스를 제공하기 위해 생물 정보학에 근거한 치료적 접근이 대두되고 있다(Fernald et al., 2011). 특히, 많은 사회적 비용을 수반하고 환자 개인 의 삶을 파괴시키는 만성 질환 중에 하나인 암 치료를 예 를 들자면, 같은 종류의 암환자라도 암이 가진 유전체, 환 자의 현재 건강 상태에 따라 가장 최적화된 치료를 제공 하고자 하는 노력이 이루어 지고 있으며 사회적 비용을 저감하고, 더불어 삶의 질 또한 증진시키려는 방향으로 의 생명 분야가 변화되고 있다. 더불어, 암 치료에서도 환자 의 장내 세균총에 따라 암 치료의 효능이 달라질 수 있다 는 연구 결과가 보고된 바 있다(Iida et al., 2013). 이와 같 이, 장내 세균총이 여러 질환에 영향을 줄 수 있는 또 하 나의 '기관'으로 인식되면서 개인이 가진 장내 세균총에 대한 표준화된 치료 표적 및 치료기술 개발을 위한 이용 가능성에 관심이 높아지고 있는 실정이다. 하지만, 개인이 가진 장내 세균총의 고유 군집은 같은 인종 및 성별이라 하더라도, 사는 지역 및 식습관, 생후 받은 모체의 질 내 정상 세균총에 따라 개별적인 장내 세균총을 형성하고 지 니고 있다(Moschen et al., 2012). 개인의 장내 세균총도 개 인이 가진 유전적, 환경적 요인들로 인해 고유한 장내 세 균총을 형성하기 때문에 앞으로 맞춤 의학이 진행 및 연 구되기 위해서는 다양한 형태의 분석 플랫폼들을(Omics 를 활용한 metagenomics, metatransriptomics, metaproteomics, metabolomics) 수반한 차세대 고성능 sequencing 기술들의 상용화 및 이용 편리성이 뒷받침 되어야만, 심혈관 질환 을 포함한 만성 질환들을 발병 및 악화시키는 특정 장내 세균총 분포 치료 전략 및 장내 세균총 분포를 변화시킬
수 있는 제제 개발 또한 수월하게 연구 및 개발될 수 있 을 것이라고 사료된다. 더불어, 이와 관련한 장내 세균총 분석 전문가들의 훈련 및 양성도 동시에 이루어지게 되면 추후 심혈관 질환을 치료하기 위한 바이오 의료 기술 개 발에도 도움이 될 것으로 사료된다.

\section{ACKNOWLEDGEMENT}

This work was supported by the National Research Foundation of Korea (NRF) grant funded by the Korean government (Ministry of Education) (2017R1D1A1A02018088) through SGER (Small Grant for Exploratory Research) program. In addition, this research was supported by the Bio \& Medical Technology Development Program of the NRF funded by the Korean government, the Ministry of Science, ICT \& Future Planning (2016M3A9B4919711).

\section{CONFLICT OF INTEREST}

The authors declare that there is no conflict of interests regarding the publication this article.

\section{REFERENCES}

Andersen NN, Jess T. Risk of cardiovascular disease in inflam0 matory bowel disease. World Journal of Gastrointestinal Pathophysiology. 2014. 5: 359-365.

Bakken JS, Borody T, Brandt LJ, Brill JV, Demarco DC, Franzos MA, Kelly C, Khoruts A, Louie T, Martinelli LP, Moore TA, Russell G, Surawicz C. Treating Clostridium difficile infection with fecal microbiota transplantation. Clinical Gastroenterology and Hepatology. 2011. 9: 1044-1049.

Brugere JF, Borrel G, Gaci N, Tottey W, O'Toole PW, MalpuechBrugere C. Archaebiotics: proposed therapeutic use of archaea to prevent trimethylaminuria and cardiovascular disease. Gut Microbes. 2014. 5: 5-10.

Caesar R, Fak F, Backhed F. Effects of gut microbiota on obesity and atherosclerosis via modulation of inflammation and lipid metabolism. Journal of Internal Medicine. 2010. 268: 320-328.

Cani PD, Bibiloni R, Knauf C, Waget A, Neyrinck AM, Delzenne NM, Burcelin R. Changes in gut microbiota control metabolic endotoxemia-induced inflammation in high-fat diet-induced obesity and diabetes in mice. Diabetes. 2008. 57: 1470-1481.

Cani PD, Lecourt E, Dewulf EM, Sohet FM, Pachikian BD, Naslain D, De Backer F, Neyrinck AM, Delzenne NM. Gut microbiota 
fermentation of prebiotics increases satietogenic and incretin gut peptide production with consequences for appetite sensation and glucose response after a meal. The American Journal of Clinical Nutrition. 2009. 90: 1236-1243.

Cani PD, Possemiers S, Van de Wiele T, Guiot Y, Everard A, Rottier O, Geurts L, Naslain D, Neyrinck A, Lambert DM, Muccioli GG, Delzenne NM. Changes in gut microbiota control inflammation in obese mice through a mechanism involving GLP2-driven improvement of gut permeability. Gut. 2009. 58: 1091-1103.

Carvalho FA, Koren O, Goodrich JK, Johansson ME, Nalbantoglu I, Aitken JD, Su Y, Chassaing B, Walters WA, Gonzalez A, Clemente JC, Cullender TC, Barnich N, Darfeuille-Michaud A, Vijay-Kumar M, Knight R, Ley RE, Gewirtz AT. Transient inability to manage proteobacteria promotes chronic gut inflammation in TLR5-deficient mice. Cell Host Microbe. 2012. 12: 139-152.

Chen Z, Guo L, Zhang Y, Walzem RL, Pendergast JS, Printz RL, Morris LC, Matafonova E, Stien X, Kang L, Coulon D, McGuinness OP, Niswender KD, Davies SS. Incorporation of therapeutically modified bacteria into gut microbiota inhibits obesity. Journal of Clinical Investigation. 2014. 124: 3391 -3406 .

Cho I, Yamanishi S, Cox L, Methe BA, Zavadil J, Li K, Gao Z, Mahana D, Raju K, Teitler I, Li H, Alekseyenko AV, Blaser MJ. Antibiotics in early life alter the murine colonic microbiome and adiposity. Nature. 2012. 488: 621-626.

David LA, Maurice CF, Carmody RN, Gootenberg DB, Button JE, Wolfe BE, Ling AV, Devlin AS, Varma Y, Fischbach MA, Biddinger SB, Dutton RJ, Turnbaugh PJ. Diet rapidly and reproducibly alters the human gut microbiome. Nature. 2014. 505: 559-563.

De Filippo C, Cavalieri D, Di Paola M, Ramazzotti M, Poullet JB, Massart S, Collini S, Pieraccini G, Lionetti P. Impact of diet in shaping gut microbiota revealed by a comparative study in children from Europe and rural Africa. Proceedings of the National Academy of Sciences of the United States of America. 2010. 107: 14691-14696.

Den Besten G, Bleeker A, Gerding A, van Eunen K, Havinga R, van Dijk TH, Oosterveer MH, Jonker JW, Groen AK, Reijngoud DJ, Bakker BM. Short-chain fatty acids protect against highfat diet-induced obesity via a PPARgamma-dependent switch from lipogenesis to fat oxidation. Diabetes. 2015. 64: 2398 -2408 .

Engervall P, Granstrom M, Andersson B, Bjorkholm M. Monitoring of endotoxin, interleukin-6 and C-reactive protein serum concentrations in neutropenic patients with fever. European Journal of Haematology. 1995. 54: 226-234.

Fernald GH, Capriotti E, Daneshjou R, Karczewski KJ, Altman RB. Bioinformatics challenges for personalized medicine. Bioinformatics. 2011. 27: 1741-1748.

Fernandes J, Su W, Rahat-Rozenbloom S, Wolever TM, Comelli EM. Adiposity, gut microbiota and faecal short chain fatty acids are linked in adult humans. Nutrition \& Diabetes. 2014. 4: e121.

Foye OT, Huang IF, Chiou CC, Walker WA, Shi HN. Early administration of probiotic Lactobacillus acidophilus and/or prebiotic inulin attenuates pathogen-mediated intestinal inflammation and Smad 7 cell signaling. FEMS Immunology and Medical Microbiology. 2012. 65: 467-480.

Frost G, Sleeth ML, Sahuri-Arisoylu M, Lizarbe B, Cerdan S, Brody L, Anastasovska J, Ghourab S, Hankir M, Zhang S, Carling D, Swann JR, Gibson G, Viardot A, Morrison D, Louise Thomas E, Bell JD. The short-chain fatty acid acetate reduces appetite via a central homeostatic mechanism. Nature Communications. 2014. 5: 3611.

Furusawa Y, Obata Y, Fukuda S, Endo TA, Nakato G, Takahashi D, Nakanishi Y, Uetake C, Kato K, Kato T, Takahashi M, Fukuda NN, Murakami S, Miyauchi E, Hino S, Atarashi K, Onawa S, Fujimura Y, Lockett T, Clarke JM, Topping DL, Tomita M, Hori S, Ohara O, Morita T, Koseki H, Kikuchi J, Honda K, Hase K, Ohno H. Commensal microbe-derived butyrate induces the differentiation of colonic regulatory $\mathrm{T}$ cells. Nature. 2013. 504: 446-450.

Gough E, Shaikh H, Manges AR. Systematic review of intestinal microbiota transplantation (fecal bacteriotherapy) for recurrent Clostridium difficile infection. Clinical Infectious Diseases. 2011. 53: 994-1002.

Ho K. Bacteriophage therapy for bacterial infections. Rekindling a memory from the pre-antibiotics era. Perspectives in Biology and Medicine. 2001. 44: 1-16.

Iida N, Dzutsev A, Stewart CA, Smith L, Bouladoux N, Weingarten RA, Molina DA, Salcedo R, Back T, Cramer S, Dai RM, Kiu H, Cardone M, Naik S, Patri AK, Wang E, Marincola FM, Frank KM, Belkaid Y, Trinchieri G, Goldszmid RS. Commensal bacteria control cancer response to therapy by modulating the tumor microenvironment. Science. 2013. 342: 967 -970 .

Jones ML, Martoni CJ, Prakash S. Cholesterol lowering and inhibition of sterol absorption by Lactobacillus reuteri NCIMB 
30242: a randomized controlled trial. European Journal of Clinical Nutrition. 2012. 66: 1234-1241.

Kelly G. Inulin-type prebiotics--a review: part 1. Alternative Medicine Review. 2008. 13: 315-329.

Kinross JM, Darzi AW. Gut microbiome-host interactions in health and disease. Genome Medicine. 2011. 3: 14.

Kleerebezem M, Vaughan EE. Probiotic and gut lactobacilli and bifidobacteria: molecular approaches to study diversity and activity. Annual Review of Microbiology. 2009. 63: 269-290.

Koeth RA, Wang Z, Levison BS, Buffa JA, Org E, Sheehy BT, Britt EB, Fu X, Wu Y, Li L, Smith JD, DiDonato JA, Chen J, Li H, Wu GD, Lewis JD, Warrier M, Brown JM, Krauss RM, Tang WH, Bushman FD, Lusis AJ, Hazen SL. Intestinal microbiota metabolism of L-carnitine, a nutrient in red meat, promotes atherosclerosis. Nature Medicine. 2013. 19: 576-585.

Koren O, Spor A, Felin J, Fak F, Stombaugh J, Tremaroli V, Behre CJ, Knight R, Fagerberg B, Ley RE, Backhed F. Human oral, gut, and plaque microbiota in patients with atherosclerosis. Proceedings of the National Academy of Sciences of the United States of America. 2011. 108: 4592-4598.

Krajmalnik-Brown R, Ilhan ZE, Kang DW, DiBaise JK. Effects of gut microbes on nutrient absorption and energy regulation. Nutrition in Clinical Practice. 2012. 27: 201-214.

Kuka J, Liepinsh E, Makrecka-Kuka M, Liepins J, Cirule H, Gustina D, Loza E, Zharkova-Malkova O, Grinberga S, Pugovics O, Dambrova M. Suppression of intestinal microbiota-dependent production of pro-atherogenic trimethylamine $\mathrm{N}$-oxide by shifting L-carnitine microbial degradation. Life Sciences. 2014. 117: 84-92.

Kwon SY, Na YA. The assessment of framingham risk score and 10 Year CHD risk according to application of LDL cholesterol or total cholesterol. Korean Journal of Clinical Laboratory Sciences. 2016. 48: 54-61.

Lalles JP. Intestinal alkaline phosphatase: multiple biological roles in maintenance of intestinal homeostasis and modulation by diet. Nutrition Reviews. 2010. 68: 323-332.

Lecomte V, Kaakoush NO, Maloney CA, Raipuria M, Huinao KD, Mitchell HM, Morris MJ. Changes in gut microbiota in rats fed a high fat diet correlate with obesity-associated metabolic parameters. PLoS One. 2015. 10: e0126931.

Lim CW, Kim JG. The usefulness of rapid triple test for cardiac marker in rorensic paragnosis of sudden cardiac death. Korean Journal of Clinical Laboratory Sciences. 2017. 49: 108-113.

Loc-Carrillo C, Abedon ST. Pros and cons of phage therapy. Bacteriophage. 2011. 1: 111-114.
Lozupone CA, Stombaugh JI, Gordon JI, Jansson JK, Knight R. Diversity, stability and resilience of the human gut microbiota. Nature. 2012. 489: 220-230.

Lundin J, Checkoway H. Endotoxin and cancer. Environmental Health Perspectives. 2009. 117: 1344-1350.

Mackensen A, Galanos C, Engelhardt R. Treatment of cancer patients with endotoxin induces release of endogenous cytokines. Pathobiology: Journal of Immunopathology, Molecular and Cellular Biology. 1991. 59: 264-267.

McCarthy DD, Kujawa J, Wilson C, Papandile A, Poreci U, Porfilio EA, Ward L, Lawson MA, Macpherson AJ, McCoy KD, Pei Y, Novak L, Lee JY, Julian BA, Novak J, Ranger A, Gommerman JL, Browning JL. Mice overexpressing BAFF develop a commensal flora-dependent, IgA-associated nephropathy. Journal of Clinical Investigation. 2011. 121: 3991-4002.

Moschen AR, Wieser V, Tilg H. Dietary factors: major regulators of the gut's microbiota. Gut Liver. 2012. 6: 411-416.

Nicholson JK, Holmes E, Kinross J, Burcelin R, Gibson G, Jia W, Pettersson S. Host-gut microbiota metabolic interactions. Science. 2012. 336: 1262-1267.

Raftery T, O'Sullivan M. Risk factors for cardiovascular events in inflammatory bowel disease. The American Journal of Gastroenterology. 2011. 106: 2042-2043.

Rohlke F, Stollman N. Fecal microbiota transplantation in relapsing Clostridium difficile infection. Therapeutic Advances in Gastro enterology. 2012. 5: 403-420.

Round JL, Mazmanian SK. The gut microbiota shapes intestinal immune responses during health and disease. Nature Reviews Immunology. 2009. 9: 313-323.

Schwartz M, Gluck M, Koon S. Norovirus gastroenteritis after fecal microbiota transplantation for treatment of Clostridium difficile infection despite asymptomatic donors and lack of sick contacts. American Journal of Gastroenterology. 2013. 108: $1367-1367$

Shen TC, Albenberg L, Bittinger K, Chehoud C, Chen YY, Judge CA, Chau L, Ni J, Sheng M, Lin A, Wilkins BJ, Buza EL, Lewis JD, Daikhin Y, Nissim I, Yudkoff M, Bushman FD, $\mathrm{Wu}$ GD. Engineering the gut microbiota to treat hyperammonemia. Journal of Clinical Investigation. 2015. 125: 2841 -2850 .

Shin NR, Whon TW, Bae JW. Proteobacteria: microbial signature of dysbiosis in gut microbiota. Trends in Biotechnology. 2015. 33: 496-503

Shin KA, Hong SB, Shin KS. Body adiposity index and metabolic syndrome risk factors in Korean adults: a comparison with 
body mass index and other parameters. Biomedical Science Letters. 2017. 23: 57-63.

Shin KA. The association of pulse pressure and pre-metabolic syndrome in Korean middle-aged men. Biomedical Science Letters. 2017. 23: 73-79.

Shin KA. Clinical usefulness of serum uric acid and resting heart rate in the diagnosis of metabolic syndrome in Korean adults. Biomedical Science Letters. 2017. 23: 118-127.

Singh V, Chassaing B, Zhang L, San Yeoh B, Xiao X, Kumar M, Baker MT, Cai J, Walker R, Borkowski K, Harvatine KJ, Singh N, Shearer GC, Ntambi JM, Joe B, Patterson AD, Gewirtz AT, Vijay-Kumar M. Microbiota-dependent hepatic lipogenesis mediated by stearoyl CoA desaturase 1 (SCD1) promotes metabolic syndrome in TLR5-deficient mice. Cell Metabolism. 2015. 22: 983-996.

Stenman LK, Waget A, Garret C, Briand F, Burcelin R, Sulpice T, Lahtinen S. Probiotic B420 and prebiotic polydextrose improve efficacy of antidiabetic drugs in mice. Diabetology \& Metabolic Syndrome. 2015. 7: 75.

Stepankova R, Tonar Z, Bartova J, Nedorost L, Rossman P, Poledne R, Schwarzer M, Tlaskalova-Hogenova H. Absence of microbiota (germ-free conditions) accelerates the atherosclerosis in ApoE-deficient mice fed standard low cholesterol diet. Journal of Atherosclerosis and Thrombosis. 2010. 17: 796-804.

Summers WC. Bacteriophage therapy. Annual Review of Microbiology. 2001. 55: 437-451.

Tang WH, Hazen SL. The contributory role of gut microbiota in cardiovascular disease. Journal of Clinical Investigation. 2014. 124: 4204-4211.

Tang WH, Wang Z, Levison BS, Koeth RA, Britt EB, Fu X, Wu Y, Hazen SL. Intestinal microbial metabolism of phosphatidylcholine and cardiovascular risk. New England Journal of Medicine. 2013. 368: 1575-1584.

Teixeira TF, Grzeskowiak L, Franceschini SC, Bressan J, Ferreira CL, Peluzio MC. Higher level of faecal SCFA in women correlates with metabolic syndrome risk factors. British Journal of Nutrition. 2013. 109: 914-919.

Trasande L, Blustein J, Liu M, Corwin E, Cox LM, Blaser MJ. Infant antibiotic exposures and early-life body mass. International Journal of Obesity. 2013. 37: 16-23.

Turnbaugh PJ, Ley RE, Mahowald MA, Magrini V, Mardis ER, Gordon JI. An obesity-associated gut microbiome with increased capacity for energy harvest. Nature. 2006. 444: 1027 -1031 .
Vrieze A, Van Nood E, Holleman F, Salojarvi J, Kootte RS, Bartelsman JF, Dallinga-Thie GM, Ackermans MT, Serlie MJ, Oozeer R, Derrien M, Druesne A, Van Hylckama Vlieg JE, Bloks VW, Groen AK, Heilig HG, Zoetendal EG, Stroes ES, de Vos WM, Hoekstra JB, Nieuwdorp M. Transfer of intestinal microbiota from lean donors increases insulin sensitivity in individuals with metabolic syndrome. Gastroenterology. 2012. 143: 913-916 e917.

Wang L, Chen Q, Qi H, Wang C, Wang C, Zhang J, Dong L. Doxorubicin-induced systemic inflammation is driven by upregulation of toll-like receptor TLR4 and endotoxin leakage. Cancer Research. 2016. 76: 6631-6642.

Wolever TM, Schrade KB, Vogt JA, Tsihlias EB, McBurney MI. Do colonic short-chain fatty acids contribute to the long-term adaptation of blood lipids in subjects with type 2 diabetes consuming a high-fiber diet? American Journal of Clinical Nutrition. 2002. 75: 1023-1030.

Wu GD, Chen J, Hoffmann C, Bittinger K, Chen YY, Keilbaugh SA, Bewtra M, Knights D, Walters WA, Knight R, Sinha R, Gilroy E, Gupta K, Baldassano R, Nessel L, Li H, Bushman FD, Lewis JD. Linking long-term dietary patterns with gut microbial enterotypes. Science. 2011. 334: 105-108.

Wu P, Jia F, Zhang B, Zhang P. Risk of cardiovascular disease in inflammatory bowel disease. Experimental and Therapeutic Medicine. 2017. 13: 395-400.

Wymore Brand M, Wannemuehler MJ, Phillips GJ, Proctor A, Overstreet AM, Jergens AE, Orcutt RP, Fox JG. The altered Schaedler flora: Continued applications of a defined murine microbial community. Institute for Laboratory Animal Research. 2015. 56: 169-178.

Xiao S, Fei N, Pang X, Shen J, Wang L, Zhang B, Zhang M, Zhang X, Zhang C, Li M, Sun L, Xue Z, Wang J, Feng J, Yan F, Zhao N, Liu J, Long W, Zhao L. A gut microbiota-targeted dietary intervention for amelioration of chronic inflammation underlying metabolic syndrome. FEMS Microbiology Ecology. 2014. 87: 357-367.

https://doi.org/10.15616/BSL.2017.23.3.166

Cite this article as: Hwang SJ, Park CO, Rhee KJ. Targeting the Gut Microbiome to Ameliorate Cardiovascular Diseases. Biomedical Science Letters. 2017. 23: 166-174. 